\begin{tabular}{|ll|}
\hline Received & $: 13$ February 2019 \\
Revised & $: 26$ March 2019 \\
Accepted & $:$ 10 September 2019 \\
Published & $:$ 27 Desember 2019 \\
\hline
\end{tabular}

\title{
Development of Teaching Materials for Writing Argumentative-Based on Lotus Teacniques on grade XII Madrasah Aliyah Negeri
}

\author{
Rika Rani $^{1, a)}$, Resdin Purba ${ }^{1, b)}$, Risnawaty ${ }^{1, c)}$ \\ Universitas Muslim Nusantara Al Washliyah, Medan, Indonesia \\ E-mail: ${ }^{\text {a) }}$ rikarani_350@gmail.com, ${ }^{\text {b) }}$ resdinpurba81@gmail.com
}

\begin{abstract}
This study aims to describe the development of teaching material patterns, the feasibility of teaching materials, and the effectiveness of teaching materials in writing paragraphs of argumentation based on lotus techniques in class XII MAN Pematangsiantar. Kind of this research is research and development based on the model of Borg and Gall. Subject trials consist of subject experts, design experts. The results showed that: (1) validation of the content experts include the freasibility of content with an average of 82,35 in very good criteria, eligibility presentation with an average of 86,545 in the very well criteria, aspects of language with an average of $90,38 \%$ in the very well criteria, (2) validation of design experts with an average of $85,00 \%$ in the very well criteria, (3) individual testing with an average of $82,87 \%$ with a very good criteria, (4) the trial of small group with an average of $91,20 \%$ with a very good criteria, and (5) a limited field test groups with an average of $95,10 \%$ with a very good criteria, (6) the effectiveness of instructional materials with a presentation by $74,22 \%$ with good criteria. Thus, the instructional materials of argumentative paragraph based on lotus tehnic that have been developed is proper to use in the learning process as a learning resource.
\end{abstract}

Keywords: intructional materials, argumentative paragraph, lotus tehnic based

\begin{abstract}
Abstrak
Penelitian ini bertujuan untuk mendeskripsikan pengembangan pola bahan ajar, kelayakan bahan ajar, dan keefektifan bahan ajar menulis paragraf argumentasi berbasis teknik teratai pada siswa kelas XII MAN Pematangsiantar. Penelitian pengembangan ini mengacu pada model Borg and Gall, yang terdiri atas materi, desain, uji coba. Data dikumpulkan melalui angket. Hasil penelitian menunjukkan bahwa: (1) validasi ahli materi kelayakan isi dengan rata-rata 82,35 pada kriteria sangat baik, kelayakan penyajian dengan rata-rata $86,54 \%$ pada kriteria sangat baik, aspek bahasa dengan ratarata $90,38 \%$ pada kriteria sangat baik, (2) validasi ahli desain dengan rata-rata $85,00 \%$ pada kriteria sangat baik, (3) uji coba perorangan dengan rata-rata $82,87 \%$ dengan
\end{abstract}


kriteria sangat baik, (4) uji coba kelompok kecil dengan rata-rata 91,20\% dengan kriteria sangat baik, dan (5) uji kelompok lapangan terbatas dengan rata-rata $95,10 \%$ dengan kriteria sangat baik, (6) keefektifan bahan ajar dengan presentasi $74,22 \%$ dengan kriteria baik. Dengan demikian, bahan ajar paragraf argumentasi berbasis teknik teratai yang telah dikembangkan layak untuk digunakan dalam proses pembelajaran sebagai sumber belajar.

Kata kunci: bahan ajar, paragraf argumentasi, berbasis teknik teratai

\section{PENDAHULUAN}

Pembelajaran bahasa Indonesia adalah bagian dari kurikulum yang menekankan pentingnya keseimbangan kompetensi sikap, pengetahuan, dan keterampilan yang berbasis teks. Pembelajaran berbasis teks memiliki implikasi terhadap pelaksanaan pembelajaran yang tidak terlepas dari teks dalam bentuk lisan maupun tulisan. Proses pembelajaran berbasis teks dilakukan secara scientific yang dikenal dengan enam $\mathrm{M}$ (mengamati, menanya, mencoba, menalar, menyaji, dan mencipta). Pembelajaran berbasis teks dilaksanakan dengan menerapkan prinsip bahwa bahasa hendaknya dipandang sebagai teks, bukan semata-mata sebagai kumpulan kata atau kaidah kebahasaan.

Kemampuan peserta didik dalam menulis teks secara tertulis merupakan persoalan yang penting. Hal ini dikarenakan keterampilan menulis merupakan keterampilan yang ekspresif, yaitu menulis melibatkan emosi dan perasaan hati yang diekspresikan dalam bentuk tulisan yang ditulis secara kreatif. Melalui karangan argumentasi siswa dapat menyampaikan gagasan, opini mereka, untuk mencapai suatu tujuan yang ingin dicapai sehingga menambah pengetahuan pembaca. Kemampuan memproduksi teks karangan argumentasi dianggap sebagai salah satu teks yang penting harus dikuasai oleh peserta didik, karena seiring perkembangan teknologi sebagai sumber belajar.

Selama ini, peserta didik merasa mengalami kesulitan dalam memahami teks karangan argumentasi. Sehingga berdampak terhadap hasil belajar siswa pada materi menulis teks karangan argumentasi dengan nilai rata-rata di bawah nilai standar. Rendahnya tingkat kelulusan siswa mengenai penulisan teks karangan argumentasi diperoleh dari hasil wawancara dengan guru bidang studi bahasa Indonesia di MAN Pematangsiantar. Selain itu siswa juga belum sepenuhnya memahami apa yang dinamakan karangan argumentasi. Unsur-unsur penulisan karangan argumentasi, dan yang paling dominan siswa belum memahami apa yang dimaksud dengan struktur dan ciri kebahasaan karangan argumentasi.

Pengembangan bahan ajar berupa modul merupakan salah satu pembaharuan yang mendukung pembelajaran bahasa Indonesia karena memiliki kelebihan yakni, dengan menggunakan modul. Peserta didik dapat mengikuti kegiatan belajar sesuai dengan kecepatan dan kemampuanya masing-masing. Kemampuan setiap peserta didik di dalam satu kelas itu pasti berbeda-beda. Melalui bahan ajar berbentuk modul, peserta didik dapat mengetahui hasil belajarnya masing-masing. Apabila tingkat 
keberhasilannya masih rendah, peserta didik dapat mempelajari kembali materi yang kurang dipahami.

Pada penelitian ini, peneliti merancang bahan ajar berbentuk modul pembelajaran yang valid. Modul ini untuk digunakan guru dan siswa dalam proses pembelajaran sesuai dengan karakteristik siswa dan potensi yang ada di sekolah. Sehingga dapat meningkatkan kreativitas dan hasil belajar peserta didik dalam menulis karangan argumentasi berbasis teknik teratai. Selain itu, pengembangan modul yang inovatif diharapkan mampu memotivasi siswa untuk belajar dan menumbuhkan minat belajar siswa. Sebagai salah satu bahan ajar cetak, modul merupakan suatu paket belajar yang berkenaan dengan satu unit bahan pelajaran dengan modul siswa dapat mencapai dan menyelesaikan bahan belajarnya dengan belajar secara individual. Peserta belajar tidak dapat melanjutkan ke suatu unit pelajaran berikutnya sebelum menyelesaikan secara tuntas materi belajarnya, dengan modul siswa dapat mengontrol kemampuan dan intensitas belajarnya (Purwahida, 2018). Modul dapat dipelajari di mana saja. Lama penggunaan sebuah modul tidak tertentu, meskipun di dalam kemasan modul juga disebutkan waktu yang dibutuhkan untuk mempelajari materi tertentu. Akan tetapi keleluasaan siswa mengelola waktu tersebut sangat fleksibel, dapat beberapa menit dan dapat pula beberapa jam, dan dapat dilakukan secara tersendiri atau diberi variasi dengan metode lain (Eriyani, 2018).

Tujuan penelitian pengembangan ini untuk mendeskripsikan analisis kebutuhan guru dan siswa mendeskripsikan hasil validasi pengembangan terhadap bahan ajar menulis karangan argumentasi berbasis teknik teratai pada siswa kelas XII MAN Pematangsiantar tahun pelajaran 2018/2019. Penelitian yang memiliki relevansi dengan penelitian ini antara lain: Haryati, dkk (2013), melakukan penelitian tentang pengembangan bahan ajar keterampilan berbahasa Indonesi untuk siswa SMA Kelas X. Hasil penelitian menunjukkan bahan ajar keterampilan berbaasa Indonesia untuk tingkat SMA sudah dikembangkan secara efektif, dan sesuai kebutuhan siswa dan kualitas bahan ajar keterampilan bahasa Indonesia tingkat SMA Kelas X pada tingkat baik. Dengan demikian, direkomendasi bahwa pengembangan produk ini dapat digunakan sebagai bahan mengajar di satuan pendidikan SMA.

Andy Syahputra Harahap (2015) tentang Pengaruh Penggunaan Teknik Teratai dalam Meningkatkan Kemampuan Menulis Puisi Siswa Kelas X SMA Al-Ulum Terpadu Medan Tahun Ajaran 2011/2012. Hasil penelitian menunjukkan bahwa hasil tes mengidentifikasi unsur bentuk puisi memperlihatkan peningkatan dari nilai rata-rata 64,52 menjadi 73,70. Berdasarkan hasil penelitian di atas, persamaan penelitian yang relevan dengan penelitian ini adalah sama-sama mengembangkan bahan ajar bahasa Indonesia. Sedangkan perbedaannya adalah lokasi penelitian, materi dan penelitian ini membahas tentang paragraf argumentasi berbasis teknik teratai.

Menurut Sholeh (2006), mengemukakan bahwa bahan ajar mencakup beberapa butir, yaitu (1) kualitas buku ajar atau buku ajar yang standar, (2) bidang studi, (3) jenjang pendidikan, (4) penyusun, (5) tujuan pembelajaran, (6) sarana pembelajaran, dan (7) program pembelajaran. Menurut Dantes (2008:4), menjelaskan bahwa bahan ajar atau materi pembelajaran (instructional materials) adalah bahan yang diperlukan untuk pembentukan pengetahuan, keterampilan, dan sikap yang harus dikuasai peserta didik dalam rangka memenuhi standar kompetensi yang ditetapkan. 
Widodo dan Jasmadi (dalam Lestari, 2013:1) bahan ajar adalah seperangkat sarana atau alat pembelajaran yang berisi materi pembelajaran, metode, batasan-batasan, dan cara mengevaluasi yang didesain secara sistematis dan menarik dalam rangka mencapai tujuan yang diharapkan, yaitu mencapai kompetensi dan subkompetensi dengan segala kompleksitasnya. Lebih lanjut Prastowo (2012:17), mendefinisikan bahan ajar merupakan buku atau program audio, video, serta komputer berisi materi pembelajaran yang "dengan sengaja" dirancang secara sistematis, walaupun dijual di pasaran bebas.

Hadirnya bahan ajar dalam kegiatan pembelajaran sangatlah membantu pendidik dan peserta didik, karena peranannya yang begitu penting. Ada dua klasifikasi utama fungsi bahan ajar sebagaimana diuraikan oleh Prastowo (2012:24): (1) Fungsi bahan ajar menurut pihak yang memanfaatkan bahan ajar. (2) Fungsi bahan ajar menurut strategi pembelajaran yang digunakan. Penyusunan bahan ajar juga harus memperhatikan aspek-aspek dalam penyusunan bahan ajar yang, meliputi (1) aspek materi, (2) aspek penyajian, (3) aspek bahasa dan keterbacaan, dan (4) aspek grafika (Sitepu 2012).

Prastowo (2012:50) menjelaskan bahwa langkah penyusunan bahan ajar meliputi tiga hal, yaitu menganalisis kurikulum, menganalisis sumber belajar, memilih dan menentukan bahan ajar. Modul merupakan bahan ajar yang disusun secara sistematis dengan bahasa yang mudah dipahami oleh siswa, sesuai usia dan tingkat pengetahuan mereka agar mereka dapat belajar secara mandiri dengan bimbingan minimal dari pendidik (Prastowo, 2012:106). Penggunaan modul dalam pembelajaran bertujuan agar siswa dapat belajar mandiri tanpa atau dengan minimal dari guru.

Menurut Russel (1974:3) adalah "...an instructional package dealing with a single conseptual unit of subject matter", sedangkan Warwich (1996) mendefinisikan modul sebagai suatu unit kurikulum yang lengkap, dan dapat ditambah dengan pencapaian tugas yang lebih besar atau tujuan-tujuan jangka panjang. Menurut penjelasan Depdiknas tahun 2008, modul merupakan sebuah buku yang ditulis dengan tujuan agar peserta didik dapat belajar secara mandiri tanpa atau dengan bimbingan guru, sehingga modul berisi paling tidak tentang (1) petunjuk belajar (petunjuk siswa/guru); (2) kompetensi yang akan dicapai; (3) content atau isi materi; (4) informasi pendukung; (5) latihan-latihan; (6) petunjuk kerja, dapat berupa Lembar Kerja (LK); (7) evaluasi; dan (8) balikan terhadap hasil evaluasi. Sebuah modul akan lebih bermanfaat apabila dapat dipahami, menarik dan mudah untuk dipergunakan. Sabri (2007:143-144) mengemukakan modul merupakan satu unit lengkap yang terdiri dari

Karakteristik modul dapat diketahui dari formatnya yang disusun atas dasar: 1) prinsip-prinsip desain pembelajaran yang berorientasi kepada tujuan (objective model) 2) prinsip belajar mandiri 3) prinsip belajar maju berkelanjutan (continuous progress) 4) penataan materi secara modular yang utuh dan lengkap (self contained) 5) prinsip rujuk silang (cross referencing) antar modul dalarn rnata pelajaran 6) penilaian belajar mandiri terhadap kemajuan belajar (self-evaluation). Kemampuan diartikan sebagai kesanggupan atau kecakapan. Kemampuan juga diistilahkan dengan kompetensi (Tarigan, 1981:11).

Menulis merupakan suatu kegiatan berkomunikasi berupa penyampaian pesan (informasi) secara tertulis kepada pihak lain dengan menggunakan bahasa tulis sebagai alat atau medianya. Aktivitas menulis melibatkan beberapa unsur yaitu, penulis sebagai 
penyampaian pesan, isi tulisan, saluran atau media dan pembaca (Dalman, 2015: 3). Menulis berarti mengorganisasikan gagasan secara sistematik serta mengungkapkannya secara tersurat (Akhadiah, 2012:2).

Kemampuan Menulis menurut Tarigan (2008:3) adalah suatu hal yang penting bahwa keterampilan menulis berfungsi sebagai alat komunikasi secara tidak langsung, tidak secara tatap muka dengan orang langsung. Suparno dan Yunus (2003:3) menyatakan bahwa menulis dapat didefinisikan sebagai suatu kegiatan penyampaian pesan (komunikasi) dengan menggunakan bahasa tulis sebagai alat medianya. Selaras dengan pernyataan sebelumnya, bahwa menulis itu merupakan proses mengomunikasikan ide atau pesan dari penulis dengan menggunakan bahasa tulis.

Menurut Widyamarta dalam Dalman (2015:85), karangan adalah bentuk tulisan dari suatu proses kegiatan berpikir manusia yang hendak menggunakan kandungan jiwanya kepada orang lain atau diri sendiri dalam tulisannya. Karangan adalah bentuk tulisan yang mengungkapkan pikiran dan perasaan pengarang dalam satu kesatuan tema yang utuh. Karangan merupakan hasil dari proses menulis dengan proses berpikir yang memiliki tujuan tertentu sesuai dengan maksud yang ingin disampaikan penulis. Karangan juga merupakan hasil penjabaran suatu gagasan secara resmi dan teratur tentang suatu topik atau pokok bahasan. Dalam karangan, seringkali seseorang membutuhkan argumen untuk mengemukakan gagasannya. Alat yang dipakai untuk mengungkapkan argumen adalah bahasa (Nurmahanani, 2016).

Menurut pendapat Dalman (2015) jenis karangan ada lima yaitu (1) deskripsi, (2) narasi, (3) eksposisi, (4) argumentasi, (5) persuasi. Karangan argumentasi adalah karangan yang bertujuan meyakinkan pembaca agar menerima atau mengambil suatu doktrin, sikap, dan tingkah laku tertentu (Dalman, 2015). Karangan argumentasi adalah karangan yang bertujuan untuk membuktikan suatu kebenaran sehigga pembaca meyakini kebenaran itu (Kosasih, 2003).

Argumentasi adalah jenis tulisan yang berisi ide atau gagasan yang dilengkapi dengan bukti-bukti kesaksian yang dijalin menurut proses penalaran yang kritis dan logis, dengan tujuan memengaruhi atau meyakinkan pembaca untuk meyatakan persetujuannya. Jika dalam eksposisi penutup tulisan adalah dengan penegasan, maka dalam tulisan berjenis argumentasi penutup karangan berupa kesimpulan (Pamungkas, 2012). Karangan argumentasi adalah bentuk bacaan yang berusaha untuk memegaruhi sikap dan pendapat orang lain, agar mereka percaya dan akhirnya bertindak sesuai dengan apa yang diinginkan (Pamungkas, 2012:61). Pendapat lain disebutkan bahwa yang dimaksud dengan karangan argumentasi adalah suatu bentuk karangan yang meyakinkan pembaca agar menerima atau mengambil suatu doktrin, sikap dan tingkah laku (Kalidjernih, 2010).

Menurut Finoza (2008), tujuan utama karangan argumentasi adalah untuk meyakinkan pembaca agar menerima atau mengambil suatu doktrin, sikap dan tingkah laku tertentu. Sedangkan syarat utama untuk menulis karangan argumentasi adalah penulisnya harus terampil dalam bernalar dan menyusun ide yang logis. Menurut Dalman (2015) langkah-langkah yang dapat ditempuh dalam menulis karangan argumentasi adalah: menentukan topik/tema; menetapkan tujuan; mengumpulkan data dari berbagai sumber; menyusun kerangka karangan sesuai dengan topik yang dipilih; dan mengembangkan kerangka menjadi karangan argumentasi. 
Karangan yang tersusun secara baik dan sempurna, panjang atau pendeknya karangan selalu mengandung tiga unsur bagian utama, yaitu (1) pendahuluan, (2) isi, (3) penutup (Tarigan, 1981).

Menurut Latifah (2010) karangan argumentasi memiliki ciri-ciri sebagai berikut: (a) berisi argumen-argumen sebagai upaya pembuktian dalam mempertahankan atau menyanggah suatu sikap/ pendapat, (b) bertujuan menyakinkan pembaca agar mengikuti apa yang dikemukakan penulis, (c) menggunakan logika atau penalaran sebagai landasan berpikir, (d) merupakan bentuk retorika yang sering digunakan dalam tulisantulisan ilmiah, dan (e) menggunakan bahasa yang bersifat rasional dan objektif dengan kata-kata yang bermakna lugas atau denotative.

Menurut Suryani (2009:20) teknik teratai merupakan teknik mengajar yang bersumber pada strategi pembelajaran kontekstual. Dalam teknik ini terdapat tiga kegiatan dasar, sesuai dengan nama teknik tersebut. Ter; terjun, at; amati, ai; rangkai. Terjun mengandung pengertian siswa langsung mengamati objek yang akan dibuat menjadi karangan dengan memanfaatkan alam lingkungan. Amati mengandung pengertian, di lapangan siswa melakukan pengamatan terhadap berbagai objek di alam sekitar. Rangkai, setelah siswa selesai mengamati dan menentukan apa-apa saja yang nanti akan dijadikannya sebagai bahan penciptaan karangan, selanjutnya siswa mulai menyusun dan merangkainya menjadi sebuah karangan. Adapun langkah-langkah pembelajaran teknik teratai yaitu bersumber dari metode kontekstual sesuai dengan pendapat Sanjaya (2006:270) yaitu: pendahuluan, inti, dan penutup.

Teknik teratai merupakan teknik mengajar yang bersumber pada strategi pembelajaran kontekstual. Contextual Teaching and Learning (CTL), suatu strategi pembelajaran yang menekankan kepada proses keterlibatan siswa secara penuh untuk dapat menemukan materi yang dipelajari dan menghubungkannya dengan situasi kehidupan nyata sehingga mendorong siswa untuk dapat menerapkannya dalam kehidupan nyata. Strategi pembelajaran kontekstual lebih menekankan keterlibatan siswa secara penuh. Siswa dianggap sebagai penentu keberhasilan belajar. Siswa didudukkan sebagai subjek belajar. Dengan berpartisipasi aktif, siswa dapat menemukan hasil belajar. Guru hanya bersifat sebagai pemandu atau fasilitator.

\section{METODE PENELITIAN}

Penelitian ini menggunakan metode penelitian dan pengembangan (research and development). Sugiyono (2015:28) mengemukakan ada beberapa istilah tentang penelitian dan pengembangan. Borg dan Gall menggunakan nama research and development (R\&D). Richey dan Kelin menggunakan nama Design and Development research. Thiagarajan menggunakan Model 4D (Define, Design, Development, and Desseminination). Dick dan Carry menggunakan istilah ADDIE (Analysis, Design, Development, Implementation, and Evaluation) (Sugiyono, 2015).

Borg dan Gall (dalam Sugiyono, 2015) menyatakan bahwa penelitian pengembangan adalah suatu proses yang digunakan untuk mengembangkan dan memvalidasi produk-produk yang digunakan dalam pendidikan dan pembelajaran. Tujuan penelitian dan pengembangan adalah ingin menilai prubahan-perubahan yang terjadi dalam kurun waktu tertentu (Setyosari, 2010). Teknik yang digunakan dalam 
pengembangan bahan ajar menulis karangan argumentasi berdasarkan pengalaman ini berupa observasi, diskusi dengan para pakar, wawancara, angket (kuesioner), serta tes kompetensi. Teknik pengumpulan data yaitu: (1) tes untuk menjaring data hasil belajar, (2) lembar angket untuk memperoleh hasil data dari ahli materi dan desain, guru bahasa Indonesia, dan siswa kelas XII MAN Pematangsiantar.

Analisis data dibagi menjadi dua jenis, yakni analisis data kualitatif dan analisis data kuantitatif. Analisis data kualitatif berupa deskriptif. Analisis data kuantitatif menggunakan statistik deskripsi (skor rata-rata dan persentase) dari angket/kuesioner, ahli materi dan desain, guru bahasa Indonesia. Uji coba produk dilakukan untuk memperoleh produk yang benar-benar bermutu, efektif serta tepat guna dan sasarannya. Uji coba produk yang dikembangkan meliputi, yaitu: (1) desain uji coba, dan (2) subjek uji coba.

Validator bahan ajar ini adalah dosen dan guru bahasa Indonesia kelas XII MAN Pematangsiantar yang berkompetan dalam pembelajaran bahasa Indonesia. Sampel yang menjadi uji coba bahan ajar (uji coba empiris) peneliti adalah siswa kelas XII MAN Pematangsaintar tahun ajaran 2018-2019 dengan jumlah 32 peserta didik.

\section{HASIL DAN PEMBAHASAN}

Produk pelaksanaan pengembangan bahan ajar menulis karangan argumentasi berbasis teknik teratai ini dilakukan secara bertahap. Tahap pertama yaitu melakukan analisis masalah dan kebutuhan di MAN Pematangsiantar yang merupakan latar belakang masalah penelitian pengembangan dengan menebar angket 3 orang guru dan 32 siswa di sekolah tersebut dengan terlebih dahulu menguraikan defenisi dari bahan ajar yang berbasis teknik teratai pada angket agar memiliki gambaran tentang pertanyaan dalam angket yang disampaikan. Hasil penelusuran dari angket ditemukan $100 \%$ dari guru dan siswa menyatakan membutuhkan bahan ajar menulis karangan argumentasi berbasis teknik teratai dalam proses pembelajaran agar berjalan lebih efektif dan dapat dijadikan siswa sebagai sarana pembelajaran secara individual.

Siswa $(82,22 \%)$ menyatakan belum mengenal bahan ajar berupa modul, sguru $(100 \%)$ telah mengenal bahan ajar berupa modul. Validasi terhadap produk bahan ajar oleh dosen dan guru dari aspek kelayakan isi materi bahwa modul menulis karangan argumentasi berbasis teknik teratai yang dikembangkan dinyatakan "sangat baik" dengan total persentase rata-rata $82,35 \%$. Penilaian aspek bahasa menurut ahli materi dinilai "sangat baik" dengan total persentasi rata-rata sebesar 90,38 \%. Hasil validasi modul oleh ahli media pembelajaran disimpulkan bahwa media pembelajaran yang dikembangkan berada pada kriteria "sangat baik" dengan total persentasi rata-rata sebesar $95,00 \%$.

Hasil respon atau tanggapan yang dilakukan oleh guru bahasa Indonesia disimpulkan bahwa modul menulis karangan argumentasi berbasis teknik teratai termasuk pada kriteria "sangat baik" dengan total persentasi rata-rata 91,91\%. Adapun indikator penilaian yaitu: (1) Penampilan modul secara keseluruhan menarik, sangat baik (100\%); (2) Pedoman penggunaan modul tersampaikan dengan jelas, sangat baik (100\%); (3) Bahasa yang digunakan dalam modul mudah dipahami, sangat baik $(87,50 \%)$; (4) Penyajian materi dalam modul tersusun secara sistematis, sangat baik 
$(87,50 \%)$; (5) Materi dalam modul sesuai dengan tujuan pembelajaran, sangat baik (100\%); (6) Penggunaan gambar dalam modul jelas, sangat baik (100\%); (7) Kegiatan pembelajaran merangsang kemampuan berpikir kritis, baik (75\%); (8) Jenis kegiatan dalam modul bervariasi, sangat baik (100\%); (9) Informasi terbaru dalam modul sesuai dengan perkembangan iptek, baik (75\%); (10) Penggunaan simbol sesuai dengan perkembangan iptek, baik (75\%); (11) Modul membantu siswa memahami materi paragraf argumentasi, sangat baik (100\%); (12) Modul berbeda dari bahan ajar biasanya, sangat baik (87,50\%); (13) Modul dapat dipelajari secara mandiri oleh siswa, sangat baik (100\%); (14) Modul melatih ssiwa memperkaya pengetahuan siswa, sangat baik (100\%); (15) Modul mempermudah guru mengevaluasi siswa, sangat baik (100\%); (16) Modul memudahkan siswa dalam menyampaikan pendapatnya dalam bentuk lisan atau tulisan, sangat baik (87,50\%); dan (17) Modul memudahkan siswa dalam menyimpulkan materi paragraf argumentasi, sangat baik $(87,50 \%)$.

Uji coba kelompok kecil dilakukan terhadap sembilan siswa dengan kemampuan tinggi, sedang dan rendah untuk mengetahui kembali persepsi siwa terhadap produk yang dikembangkan dan yang telah direvisi dari kelemahan-kelemahan setalah dilakukan uji coba perorangan. Hasilnya menunjukkan bahwa modul yang dikembangkan termasuk pada kriteria "sangat baik" dengan total persentasi rata-rata sebesar 91,20\%.

Uji coba kelompok lapangan terbatas dilakukan terhadap 32 siswa dengan kemampuan tinggi, sedang, dan rendah. Hasil respon siswa uji coba kelompok lapangan terbatas disimpulkan bahwa modul termasuk dalam kriteria "sangat baik" dengan persentasi skor rata-rata sebesar 95,10\%. Ahli materi menilai bahan ajar berupa modul karangan argumentasi berbasis teknik teratai untuk siswa kelas XII yang dikembangkan ini telah memiliki kelayakan isi dengan persentase skor rata-rata 82,35\% dengan kriteria "sangat baik", memiliki kelayakan dengan persentase skor rata-rata 87,50\% dengan kriteria "sangat baik". Dan aspek bahasa menunjukkan persentase skor rata-rata 90,38\% dengan kriteria "sangat baik". Berdasarkan skor rata-rata tersebut menunjukkan bahwa bahan ajar berupa modul yang telah dikembangkan dapat memenuhi tuntutan kebutuhan pembelajaran.

Berdasarkan hasil persentase dari ahli materi tentang kelayakan Isi pada subkomponen penilaian terhadap kesesuaian materi dengan indikator memiliki persentase rata-rata $91,67 \%$, keakuratan materi dengan rata-rata $76,79 \%$, kemutahiran materi dengan rata-rata $82,50 \%$. Hasil persentase rata-rata dari keseluruhan bab komponen penilaian aspek kelayakan penyajian isi adalah 82,35\% dengan kriteria"sangat baik". Pada kelayakan penyajian, ahli materi menilai bahan ajar berupa modul karangan argumentasi berbasis teknik teratai yang dikembangkan telah memiliki kelayakan penyajian dengan persentase skor rata-rata $87,50 \%$ dengan kriteria "sangat baik".

Berdasarkan hasil persentase dari ahli materi tentang kelayakan penyajian pada subkomponen penilaian terhadap teknik penyajian memiliki persentase rata-rata $100,00 \%$ penyajian pembelajaran dengan rata-rata 91,67 \%, dan kelengkapan penyajian dengan rata-rata $82,81 \%$. Hasil persentase rata-rata dari keseluruhan subkomponen penilaian aspek kelayakan penyajian adalah 87,50\% dengan kriteria "sangat baik".

Penilaian bahasa, ahli materi menilai bahan ajar berupa modul menulis karangan argumentasi berbasis teknik teratai yang dikembangkan telah memiliki kelayakan 
bahasa dengan persentase skor rata-rata 90,38\% dengan kriteria "sangat baik". Ahli desain bahan ajar berupa modul menulis karangan argumentasi berbasis teknik teratai yang dikembangkan telah memiliki kelayakan dengan persentase skor rata-rata $95,00 \%$.

Hasil uji coba perorangan tentang persepsi siswa terhadap modul yang telah dikembangkan menunjukkan presentase rata-rata $82,87 \%$ dengan kriteria "sangat baik". Uji coba perorangan dilaksanakan untuk mengetahui tanggapan awal siswa sebagai dan untuk mengidentifikasi kekurangan produk terhadap produk yang dikembangkan sebelum dilakukannya uji coba kelompok kecil. Uji keefektifan bahan ajar modul menulis karangan argumentasi berbasis teknik teratai dilakukan kepada siswa kelas XII dengan menggunakan tes. Tes yang dilakukan ada dua jenis yaitu, pretes dan postes. Hasil dari rekapitulasi data yang diperoleh dari pretes dan postes, adalah tes awal (pretes) siswa memperoleh jumlah 2010 dengan rata-rata 62,81 berada pada kriteria "cukup baik", sedangkan pada tes akhir (postes) memperoleh jumlah 2375 dengan ratarata 74,22 pada kriteria "baik".

Berdasarkan analisis data yang dilakukan tentang hasil belajar sebelum menggunakan bahan ajar menulis karangan argumentasi berbasis teknik teratai memperoleh skor rata-rata 62,81 dengan kriteria penilaian pada kategori "cukup baik", artinya nilai yang dicapai siswa pada materi menulis karangan argumentasi sudah mencapai harapan, namun perlu ditingkatkan lagi. Analisis data yang dilakukan tentang hasil belajar sesudah menggunakan bahan ajar menulis karangan argumentasi berbasis teknik teratai memperoleh skor rata-rata 74,22 dengan kriteria penilaian pada kategori "baik" artinya nilai yang dicapai siswa pada materi paragraf argumentasi dengan baik.

Hasil pretes dan postes yang diberikan pada siswa juga terlihat adanya peningkatan hasil belajar yang diajarkan dengan menggunakan bahan ajar berupa modul yang telah dikembangkan. Penelitian dan pengembangan dilakukan dengan tujuan untuk menghasilkan produk berupa bahan ajar berbasis teknik teratai. Sekaligus menguji keefektifan produk yang dapat dimanfaatkan siswa kelas XII MAN Pematangsiantar sebagai salah satu upaya untuk meningkatkan kualitas pembelajaran. Oleh karena itu, proses penelitian dan pengembangan ini dilakukan dan diawali dengan beberapa tahap antara lain (1) Melakukan studi pendahuluan melalui observasi dan studi pustaka. Dari hasil observasi diperoleh data bahwa siswa sangat membutuhkan bahan ajar berupa modul. (2) Mendesain produk untuk menghasilkan produk awal bahan ajar. (3) Mengembangkan bahan ajar. Kegiatan ini meliputi kata pengantar, indikator, kegiatan belajar, dan daftar pustaka. (4) Perancangan kegiatan pembelajaran meliputi materi pembelajaran, rangkuman, tes, dan kunci jawaban. (5) Melakukan validasi dan revisi, kegiatan ini meliputi evaluasi produk untuk mengetahui kelebihan dan kelemahan mengenai kualitas isi dan desain yang dilakukan oleh ahli materi dan ahli desain. Dari hasil evaluasi akan dijadikan bahan untuk dilakukan revisi produk. (6) Melakukan uji coba perorangan, uji coba kelompok kecil, dan uji coba lapangan terbatas sehingga dihasilkan bahan ajar berupa modul menulis karangan argumentasi berbasis teknik teratai untuk siswa kelas XII MAN Pematangsiantar yang layak digunakan.

Hasil validasi dari ahli materi dalam pengembangan bahan ajar berbasis teknik teratai untuk siswa menunjukkan bahwa kelayakan isi dengan rata-rata 82,35 pada kriteria sangat baik, kelayakan penyajian dengan rata-rata 86,545 pada kriteria sangat baik, dan kelayakan bahasa dengan rata-rata 90,38 \% pada kriteria sangat baik. Dengan 
demikian, bahan ajar berbasis teknik teratai berupa modul yang dikembangkan secara keseluruhan termasuk dalam kriteria"sangat baik".

Hasil validasi dari ahli desain terhadap kelayakan desain dalam pengembangan bahan ajar berupa modul menulis karangan argumentasi berbasis teknik teratai untuk siswa yang dikembangkan menunjukkan bahwa ukuran modul memiliki persentase ratarata $87,50 \%$ pada kriteria sangat baik, desain sampul modul dengan rata-rata $88,89 \%$ pada kriteria sangat baik, dan desain isi modul dengan rata-rata 82,89\% pada kriteria sangat baik. Hasil persenyase rata-rata dari keseluruhan sub komponen penilaian kelayakan penyajian adalah 85,00\% dengan kriteria"sangat baik". Dengan demikian, kelayakan desain bahan ajar berbasis teknik teratai berupa modul yang dikembangkan dapat dijadikan pola desain yang akan digunakan siswa.

Hasil data diperoleh dari guru, menyatakan bahwa bahan ajar berupa modul menulis karangan argumentasi berbasis teknik teratai untuk siswa kelas XII yang dikembangkan dengan rata-rata 91,91\% pada kriteria "sangat baik". Hal ini sesuai dengan hasil penelitian Gagne dan Briggs (1992) yang menyatakan bahwa bahan ajar yang terbaik tidak akan memenuhi fungsi dan perananya jika bahan ajar tidak disukai oleh seorang pengajar.

Data-data yang diperoleh dari siswa bahwa bahan ajar berupa modul menulis karangan argumentasi berbasis teknik teratai yang dikembangkan sesuai dengan penilaian indikator dalam pernyataan secara keseluruhan menunjukkan bahwa (1) persentase rata-rata dari uji coba perorangan adalah $82,87 \%$ dengan kriteria ' sangat baik", dan (3) persentase rata-rata dari uji kelompok lapangan terbatas adalah $95,10 \%$ dengan kriteria "sangat baik". Data hasil respon siswa terhadap modul yang dikembangkan mengalami peningkatan yaitu peningkatan sebesar 8,33\% dari uji perorangan ke uji coba kelompok kecil, dan peningkatan 3,90\% dari uji coba kelompok kecil ke uji coba kelompok lapangan terbatas.

Menurut Belawati (2003) sebuah bahan ajar dianggap final setelah memperlihatkan hasil yang memuaskan dalam mencapai tujuan yang telah ditentukan. Untuk hal ini diperlukan uji coba produk pada proses pembelajaran untuk mengetahui keefektifan produk. Untuk melihat keefektifan produk dilakukan analisis hasil belajar pada 32 orang siswa yang diajarkan dengan menggunakan bahan ajar yang dikembangkan dan dibandingkan dengan hasil belajar siswa yang diajarkan dengan buku teks. Berdasarkan anlaiis, nilai rata-rata pada kompetensi dasar menggunakan bahan jaar berbasis tehik teratai lebih tinggi dengan jumlah 2375 dengan rata-rata $74,22 \%$ dibandingkan nilai-rata-rata siswa sebelum menggunakan bahan ajar berupa odul yang berjumlah 2010 dengan rata-rata 62,81. Sehinggga dapat dinyatakan bahwa terdapat perbedaan hasil belajar antara siswa yang menggunakan bahan jara berbasis teknik teratai terhadap menggunakan buku teks dan disimpulkan bahwa bahan ajar hasil pengembangan efektif dan layak dipakai sebagai sumber belajar.

\section{KESIMPULAN}


Produk bahan ajar berbasis teknik teratai yang dikembangkan pada materi karangan argumentasi untuk siswa kelas XII MAN Pematangsiantar memenuhi syarat dan layak digunkan berdasarkan validasi ahli materi meliputi kelayakan isi dengan ratarata 82,35 pada kriteria sangat baik, kelayakan penyajian dengan rata-rata $86,54 \%$ pada kriteria sangat baik, kelayakan penyajian dengan rata-rata $86,54 \%$ pada kriteria sagat baik, aspek bahasa dengan rata-rata $90,38 \%$ pada kriteria sangat baik, dan validasi ahli desain dengan rata-rata $85,00 \%$ pada kriteria sangat baik.

Pola bahan ajar berbasis teknik teratai pada materi karangan argumentasi tergolong sangat baik dan sesuai dengan kebutuhan siswa, dinilai dari respon dua orang guru yang rata-rata $91,91 \%$ dengan kriteria sangat baik dan 32 orang siswa memiliki persentase $95,10 \%$ denga kriteria sangat baik.

Penggunaan bahan ajar berbasis teknik teratai lebih efektif meningkatkan hasil belajar siswa. Hal ini ditunjukkan hasil belajar siswa yang diajarkan menggunakan bahan ajar yang dikembangkan lebih tinggi berjumlah 2375 dengan rata-rata 74,22 dari hasil belajar siswa yang belajar dengan nmenggunakan buku teks.

Produk hasil penelitian pengembangan bahan ajar menulis karangan argumentasi berbasis teknik teratai ini diharapkan dapat mendukung upaya guru dalam pengembangan bahan ajar yang bersumber dari pengalaman siswa. Dapat digunakan sebagai bahan ajar tambahan bagi siswa untuk meningkatkan pemahaman siswa khususnya dalam menulis teks karangan argumentasi.

Produk hasil penelitian pengembangan bahan ajar menulis karangan argumentasi berbasis teknik teratai ini diharapkan dapat digunakan sebagai acuan untuk pengembangan bahan ajar lainnya dengan pendekatan serupa maupun pendekatan lainnya.

\section{REFERENSI}

Akhadiah, S. (2012). Pembinaan Kemampuan Menulis Bahasa Indonesia. Jakarta: Erlangga.

Ambarawati, Y. (2015). Pembelajaran keterampilan menulis karangan argumentasi (Studi Kasus di Kelas X Tata Busana Butik SMK Negeri 4 Sukoharjo). Universitas Sebelas Maret. Volume 3 Nomor 2 (3-4)

Belawati, T. (2003). Pengembangan Bahan Ajar. Jakarta: Universitas Terbuka.

Dalman. (2015). Keterampilan Menulis. Jakarta: Rajawali Pers.

Dantes, N. (2008). Pengembangan Bahan Ajar Dalam Kaitan dengan Implementasi KTSP. Makalah disajikan dalam Workshop Pengembangan Bahan Ajar Pada PGRI Kecamatan Manggis Karangasem.

Darmayanti, I. (2014). Peningkatan Keterampilan Menulis Paragraf Argumentasi Melalui Pembelajaran Berbasis Masalah. Jurnal Pendidikan dan Pembelajaran Nomor 2-3 
Eriyani, R. N. (2018). Bahan Ajar Menulis Bermuatan Lokal Bagi Siswa Sman 1 Cipanas Kabupaten Lebak (Kajian Deskriptif). Aksis: Jurnal Pendidikan Bahasa dan Sastra Indonesia 2(2). 275-284. doi: doi.org/10.21009/AKSIS.020208

Finoza, L. (2008). Komposisi Bahasa Indonesia Untuk Mahasiswa Nonjurusan Bahasa. Jakarta: Diksi Insan Mulia.

Gagne, R.M. dan Briggs, L.J. (1992). Principles of Instructional Design (4 Ed). New York: Holt, Rinehart and Winston.

Harahap, Andy Syahputra. (2015). Pengaruh Penggunaan Teknik Teratai dalam Meningkatkan Kemampuan Menulis Puisi Siswa Kelas X SMA Al-Ulum Terpadu Medan Tahun Ajaran 2011/2012. Jurnal Edukasi Kultura, 2(2), September 2015, 127-148.

Haryati, dkk. (2013). Pengembangan Bahan Ajar Keterampilan Berbahasa Indonesia untuk Siswa Kelas XII. Tekno-Pedagogi.vol 3(2):35-41.

Hidayati, F. (2014). Keefektifan Metode Kontekstual Teknik Teratai (Terjun, Amati, Rangkai) Dalam Pembelajaran Keterampilan Menulis Puisi Pada Siswa Kelas VII SMP Negeri 2 Depok Sleman Yogyakarta. Universitas Negeri Yogyakarta. Volume 3 Nomor 2.

Kalidjernih, F.K. (2010). Kamus Studi Kewarganegaraan: Perspektif Sosiologikal dan Politikal. Jakarta: Widya Aksara Press.

Karawasa, H. (2017). Meningkatkan Kemampuan Menulis Karangan Sederhana Siswa Kelas IV SDN Mire Melalui Penggunaan Media Gambar Seri. Jurnal Universitas Tadulako. Volume 5 Nomor 2

Kosasih, E. (2003). Kompetensi Ketatabahasaan dan Kesusasteraan Cermat Berbahasa Indonesia. Bandung: CV. Irama Widya.

Lestari, Sri. (2013). Psikologi Keluarga: Penanaman Nilai dan Penanganan Konflik Dalam Keluarga. Jakarta: Kencana.

Lida, Ulfah M.., \& Ida Z.,. (2017). Pola Penalaran Dalam Karangan Argumentasi Pada Siswa Tahap Operasi Formal. Journal Indonesian Language Education and Literature. Vol. 3, No. 1, Desember 2017 (48)

Lubis, Mina S. et.al. (2014). Pengembangan Modul Pembelajaran Bahasa Indonesia Berbantuan Peta Pikiran Pada Materi Menulis Makalah Siswa Kelas XI SMA/MA. Jurnal Bahasa, Sastra dan Pembelajaran. Vol 2, No. 1 (2014) (19)

Miftahul, G. (2017). Meningkatkan Keterampilan Menulis Karangan Narasi Melalui Model PWIM (Picture Word Inductive Model) Siswa Kelas IV B SD Negeri Ketib Kecamatan Sumedang Utara Kabupaten Sumedang. Universitas Pendidikan Indonesia. Volume 2 , Nomor 1.

Nurjaya, G. (2012). Pengembangan Bahan Ajar Metode Pembelajaran Bahasa Dan Sastra Indonesia Berbasis Pembelajaran Kooperatif Jigsaw Untuk Meningkatkan Pemahaman Dan Kemampuan Aplikatif Mahasiswa. Jurnal Pendidikan Indonesia. Vol. 1, No. 2, Oktober 2012 (104) 
Pamungkas, S. (2012). Bahasa Indonesia dalam Berbagai Perspektif: Dilengkapi dengan Teori, Aplikasi, dan Analisis Penggunaan Bahasa Indonesia. Jakarta: Andi.

Prastowo, A. (2012). Pengembangan Sumber Belajar. Yogyakarta: Pedagogia.

Prihastuti, E. N. (2011). Keefektifan Penggunaan Media Wall Chart (bagan dinding) dalam Meningkatkan Kemampuan Menulis Karangan Argumentasi Siswa Kelas X SMA Negeri 1 Seyegan sleman, Skripsi. Sarjana Universitas Negeri Yogyakarta.

Purwahida, R. (2018). Problematika Pengembangan Modul Pembelajaran Baca Tulis Anak Usia Sekolah Dasar. Aksis: Jurnal Pendidikan Bahasa dan Sastra Indonesia 2(1). 118-134. doi: doi.org/10.21009/AKSIS.020108

Rojaki. (2012). Upaya Meningkatkan Kemampuan Menulis Puisi Melalui Model Pembelajaran Sinektik Siswa Kelas X 3 SMA Negeri 2 Sekayu. Jurnal Ilmiah Guru, Nomor 2.

Sanjaya, Wina. (2006). Pembelajaran dalam Implementasi Kurikulum Berbasis Kompetensi. Jakarta: Kencana.

Setyosari, Punaji. (2010). Metode Penelitian Pendidikan dan Pengembangan. Jakarta: Kencana Prenada Media.

Sholeh. (2006). Psikologi Perkembangan. Jakarta: PT Rineka Cipta.

Sitepu, B.P. (2012). Penulisan Buku Teks Pelajaran. Bandung: PT. Remaja Rosdakarya.

Sugiyono. (2015). Metode Penelitian dan Pengembangan (Research and Development/ $R \& D$. Bandung: Alfabeta.

Sungkono. (2009). Pengembangan dan Pemanfaatan Bahan Ajar Modul dalam Proses Pembelajaran. Yogyakarta: Universitas Negeri Yogyakarta.

Suryani. (2009). Efektivitas Penggunaan Teknik Teratai dalam Meningkatkan Kemampuan Menulis Puisi Pada Siswa Kelas X SMA Negeri 6 Cimahi Tahun Ajaran 2009/2010. Skripsi, UPI, 2009.

Tarigan, H. G. (1981). Menulis Sebagai Suatu Keterampilan Berbahasa. Bandung: Angkasa.

Tina, R, et.al. (2013). Peningkatan Pembelajaran Menulis Argumentasi Melalui Model Pembelajaran Brainstorming. Jurnal Pendidikan Bahasa dan Sastra Indonesia, Vol.1, No.2 Maret 2013 